\title{
Establishment of Grass Strips for Maintaining Biodiversity in Agroecosystems
}

\author{
Yanko Dimitrov ${ }^{1}$, Nedyalka Palagacheva ${ }^{1}$, Rositsa Mladenova ${ }^{2}$, Plamen Zorovski ${ }^{1}$, Stoyan Georgiev ${ }^{3}$, \\ Zheko Radev ${ }^{1}$, Milena Dimova ${ }^{1} \&$ Lilko Dospatliev ${ }^{4}$ \\ ${ }^{1}$ Agricultural University, Plovdiv, Bulgaria \\ ${ }^{2}$ Syngenta Bulgaria Ltd., Sofia, Bulgaria \\ ${ }^{3}$ Field Crops Institute, Chirpan, Bulgaria \\ ${ }^{4}$ Thracian University, Stara Zagora, Bulgaria \\ Correspondence: Yanko Dimitrov, Agricultural University, 12 Mendeleev Buld., 4000 Plovdiv, Bulgaria. Tel: \\ 359-32-654-271. E-mail: dimitrov_ento@abv.bg
}

Received: December 12, 2017

doi:10.5539/jas.v10n3p90
Accepted: January 16, $2018 \quad$ Online Published: February 15, 2018

URL: https://doi.org/10.5539/jas.v10n3p90

\begin{abstract}
Main principle of the common agricultural policy of European Union is achievement of high results with the least possible negative impact on the environment, land protection and efficient use of natural resources. For that purpose, a number of studies are carried out, related to the improvement of biodiversity and protection of the pollinators in the areas of production. Two type of grass mixes were observed: "Laitamag" (Hungary) composed of White mustard (Sinapis alba L.), White clover (Trifolium repens L.), Phacelia (Phacelia tanacetifolia Bentham), Crimson clover (Trifolium incarnatum L.), Egyptian clover (Trifolium alexandrinum L.), Red clover (Trifolium pretense L.), Wild oats (Avena sativa L.), Alfalfa (Medicago sativa L.), Buckwheat (Fagopyrum esculentum Moench) and Sainfoin (Onobrychis viciifolia Scop.) and a mix, proposed by the Agrarian University: White mustard (Sinapis alba L.), White clover (Trifolium repens L.), Phacelia (Phacelia tanacetifolia Bentham), Buckwheat (Fagopyrum esculentum Moench), Coriander (Coriandrum sativum L.). The vegetation of the autumn crops began in March, as the blossoming lasts for 60-63 days, from the beginning of April until 24 June. For the spring sowing (18 March), the flowering of the mixes occurred later, in the second 10-day period of May and ended at the end of June. As a result of the low temperatures during winter, the white mustard, buckwheat and sainfoin plants perished. White clover proves to be the most resilient species.
\end{abstract}

Keywords: biodiversity, grass mix, pollinators

\section{Introduction}

The intensive use of agricultural areas for solving the food provision issues, the ever growing global population and the climate changes often result in a loss of the natural habitats of organisms (Pollinators and Agriculture, 2013; Pesticides and Biodiversity, 2011). This results in brakage of the balance in the ecosystems and cause favourable conditions for episodic amplification of certain insect species, which possess economic significance as pests.

In the agricultural ecosystems in Europe, approximately $80 \%$ of all crops are pollinated by insects, such as bumblebees, honeybees, butterflies etc. Yields of certain fruit-tree species and plants decrease by over $90 \%$ in the absence of insects-pollinators (Klein et al., 2007). In the period 1985-2005 the bee colonies decreased by an average of 16\%, and in certain European countries, such as United Kongdom, Germany, the Czech Republic and Sweden, the percentage is reported to be much higher. The number of wild bee colonies also decreased as a result of the effect of a number of factors (STEP, 2007). Some authors reported for decline in pollinators but they focus on the improvement of the available habitats, which is in line with EU's common agricultural policy (Westphal et al., 2003).

Some authors ascribe the decline in the numbers of the bee populations to the lack of habitats (Richards, 2001; Kremen et al., 2002; Larsen et al., 2005). Others indicate that bee families in agrocenoses decreased as a result of chemical operations, related to the plant protection measures (Kevan, 1997; Desneux et al., 2007; Johnson et al., 2010). One possibility to limit the adverse effects of the chemical method is establishing of self-regulating 
agrocenoses with rich species diversity of living organisms. This is also the main objective for the sustainable development of agricultural areas in Bulgaria and corresponds to European Union's common agricultural policy.

In order to improve the biodiversity in agricultural areas, it is necessary to establish new habitats for pollinators at the perimeter of agricultural land. Flower meadows, strips of blossoming plants, field-protection belts, buffer strips have been established in some European countries to provide sources of food and habitats for the living organisms, as well as a depot for the multiplication of pollinators and for attracting honey bees, ensuring high economic results of the production.

There are developped some international initiatives to reinstate the natural habitats and to provide essential food for pollinators, like "Operation Pollinator" (Syngenta global project). It demonstates that environmental management and intensive agriculture can co-exist in the same field. In this way, agricultural producers in Europe and around the world establish and maintain habitats for pollinators in agricultural areas (Isaacs et al., 2010). Operation Pollinator helps growers across Europe in successfully establishment and management of essential habitat for pollinating insects on commercial farms. The initiative was realized with the involvement of more than 2500 farmers from countries, such as: Belgium, the United Kingdom, France, Germany, Greece, Hungary, Ireland, Spain, Portugal, Sweden, Switzerland, Bulgaria etc.

Main objective of the study is to test the germination and development of different grass mixtures to establisg flowering strips, attracting pollinators near production areas.

\section{Mehods}

This study was conducted in the period 2013-2015 at the Educational Experimental and Implementation Facility of the Agrarian University, Plovdiv. Two types of grass mixes were chosen for the trials: comersial mixture of Laitamag (Hungary) and locally developed by Agrarian University, Plovdiv. Both mixes were tested with two types of sowing (autumn and spring).

The Laitamag Mix is composed of ten species of plants in the following ratios: White mustard (Sinapis alba L.) (5\%), White clover (Trifolium repens L.) (5\%), Phacelia (Phacelia tanacetifolia Bentham) (5\%), Crimson clover (Trifolium incarnatum L.) (10\%), Egyptian clover (Trifolium alexandrinum L.) (10\%), Red clover (Trifolium pretense L.) (20\%), Wild oats (Avena sativa L.) (5\%), Alfalfa (Medicago sativa L.) (10\%), Buckwheat (Fagopyrum esculentum Moench) (15\%) and Sainfoin (Onobrychis viciifolia Scop.) (15\%).

The mix, proposed by the Agrarian University consists of five plant species in the following ratios: White mustard (Sinapis alba L.) (10\%), White clover (Trifolium repens L.) (30\%), Phacelia (Phacelia tanacetifolia Bentham) (25\%), Buckwheat (Fagopyrum esculentum Moench) (15\%), Coriander (Coriandrum sativum L.) (20\%).

The sowing rate for both mixtures was $20 \mathrm{~kg} / \mathrm{ha}$, and the depth of sowing was $1.0-1.5 \mathrm{~cm}$. The test area was $420 \mathrm{~m}^{2}$ $(6 \times 70 \mathrm{~m})$. The autumn sowing was performed on October 29, 2013, and the spring on March 18, 2014. Before and after sowing, the terrain was rolled. The sowing density and species ratios was recorded per $\mathrm{m}^{2}$, based on a sampling plot.

The plot-test plots, applied for the sowing of the studied grass mixes were as follows:

Plot I: Laitamag (autumn sowing)

Plot II: Agrarian University (autumn sowing)

Plot III: Laitamag (spring sowing)

\section{Plot IV: Agrarian University (spring sowing)}

The germination, wintering of the plants (in the case of autumn sowing), their development, species distribution and density of the strands was monitored.

\section{Results and Discussion}

The favourable weather conditions in the autumn of 2013 and the spring of 2014 enabled good garnished stands of the crops, in accordance with the sown species and the grass mix ratios.

Although mild, with temperatures around $0{ }^{\circ} \mathrm{C}$, but without any snow cover, winter had an adverse effect on some species, reducing their number $/ \mathrm{m}^{2}$ and changing the original plant ratio in the sown areas. White mustard manifested itself as being very sensitive to low temperatures, and therefore it was destroyed by frost in Plot II. The stand densities in the spring showed that of all plants, included in both mixes, the white clover was the most resistant to cold. 
As a result of the respective plasticity, competitiveness and ratios of the species in the composition of both mixes (Laitamag and Agrarian University), different strand density was reported in the spring of 2014. For the Laitamag grass mix it was 59.8 plants $/ \mathrm{m}^{2}$, and in the Agrarian University mix - $228.4 \mathrm{pcs} . \mathrm{m}^{2}$ (Tables 1 and 2).

Table 1. Plot I: Laitamag grass mix (Hungary), autumn sowing in 2013

\begin{tabular}{lll}
\hline & Species & \multirow{2}{*}{ Average number of plants $/ \mathrm{m}^{2}$} \\
\hline Common name & Latin name & \\
Alfalfa & Sinapis alba $\mathrm{L}$. & 5.2 \\
Phacelia & Medicago sativa L. & 13.6 \\
Egyptian clover & Phacelia tanacetifolia Bentham & 3.6 \\
Crimson clover & Trifolium alexandrinum L. & 12.8 \\
Wild oats & Trifolium incarnatum L. & 2.6 \\
White clover & Avena sativa L. & 14.4 \\
Total & Trifolium repens L. & 59.8 \\
\hline
\end{tabular}

Table 2. Plot II: Agrarian University grass mix, autumn sowing in 2013

\begin{tabular}{lll}
\hline & Species & \multirow{2}{*}{ Average number of plants $/ \mathrm{m}^{2}$} \\
\hline Common name & Latin name & \\
\hline Coriander & Coriandrum sativum L. & 73.8 \\
Phacelia & Phacelia tanacetifolia Bentham & 49.8 \\
White clover & Trifolium repens L. & 104.8 \\
Total & & 228.4 \\
\hline
\end{tabular}

The reduced density in the first plot as a result of the winter conditions are most apparent, if compared to the spring sowing-Plot III. The reported strand density was $263.5 \mathrm{pcs} / \mathrm{m}^{2}$, and $272.4 \mathrm{pcs} / \mathrm{m}^{2}$ in Plot IV. The values for Plot II and IV (Agrarian University-autumn, spring sowing) were relatively close, showing that the commercialized mix (Hungary) is sensitive to the low winter temperatures in the Plovdiv region (Tables 3 and 4).

Table 3. Plot III: Laitamag grass mix (Hungary), spring sowing in 2014

\begin{tabular}{lll}
\hline & Species & \multirow{2}{*}{ Average number of plants $/ \mathrm{m}^{2}$} \\
\hline Common name & Latin name & \\
white mustard & Sinapis alba L. & 16.4 \\
alfalfa & Medicago sativa L. & 51.0 \\
Egyacelia & Phacelia tanacetifolia Bentham & 67.8 \\
crimson clover & Trifolium alexandrinum L. & 13.7 \\
wild oats & Trifolium incarnatum L. & 26.4 \\
white clover & Avena sativa L. & 3.8 \\
buckwheat & Trifolium repens L. & 77.6 \\
Total & Fagopyrum esculentum Moench & 6.8 \\
\hline
\end{tabular}

Table 4. Plot IV: Agrarian University grass mix, spring sowing in 2014

\begin{tabular}{lll}
\hline & Species & \\
\hline Common name & Latin name & Average number of plants $/ \mathrm{m}^{2}$ \\
\hline white mustard & Sinapis alba L. & 41.6 \\
coriander & Coriandrum sativum $\mathrm{L}$. & 54.0 \\
phacelia & Phacelia tanacetifolia Bentham & 4.0 \\
white clover & Trifolium repens L. & 162.2 \\
buckwheat & Fagopyrum esculentum Moench & 10.6 \\
Total & & 272.4 \\
\hline
\end{tabular}


As for the plots with autumn sowing, in plot I the blossoming commenced in April and ends in the beginning of June. The blossoming of the Agrarian University mix commenced approximately one month later and ended at the end of June. For both plots, the duration of the blossoming was 60-63 days, as in Plot I the blossoming period was April-May, and for Plot II-May-June.

In the case of the spring sowing, for both plots (III and IV) the blossoming commenced in the second decade of May and ended at the end of June - 40 days. Its duration was 20 days less and ensured a blossoming period 1- 2 months later than the plots of the autumn sowing. The duration of the blossoming of the individual species, composing the mixes was different, as the blossom corresponded to the plant species included in their composition.

For the plots with autumn sowing (I and II) white mustard started blossoming the earliest-from the beginning of April until the beginning of May, and as a result, the blossoms were of a single, predominantly yellow colour. The blossoming species from the end of April (28.04) and until the end of May (28.05) were phacelia and crimson clover (08.05-28.05). They formed two levels in the grass mix: top purple-coloured and bottom red. The Egyptian and white clover blossomed in the period 28.05-04.06 and form the white blossom in the mix (Table 5).

Table 5. Blossoming period of the grass mixes in 2014

\begin{tabular}{|c|c|c|}
\hline \multicolumn{3}{|c|}{ Plot I: Laitamag grass mix (Hungary) (Autumn sowing) } \\
\hline Blossoming Period & Plant & Blossom \\
\hline $02.04-25.04$ & White mustard & Yellow \\
\hline 25.04-08.05 & White mustard and phacelia & Yellow and purple \\
\hline 08.05-28.05 & Phacelia & Purple: 1 st level \\
\hline & Crimson clover & Red: 2nd level \\
\hline $28.05-04.06$ & Phacelia & Purple: 1st level \\
\hline & White and Egyptian clover & White: 2nd level \\
\hline \multicolumn{3}{|c|}{ Plot II: AU grass mix (Autumn sowing) } \\
\hline Blossoming Period & Plant & Blossom \\
\hline $25.04-28.05$ & Phacelia & Purple \\
\hline $28.05-24.06$ & Coriander and white clover & White \\
\hline \multicolumn{3}{|c|}{ Plot III: Laitamag grass mix (Hungary) (Spring sowing) } \\
\hline Blossoming Period & Plant & Blossom \\
\hline $20.05-27.05$ & White mustard & Yellow \\
\hline 27.05-09.06 & White mustard and phacelia & Yellow and purple \\
\hline $10.06-15.06$ & Phacelia and white mustard & Purple and yellow: 1 st level \\
\hline & Crimson clover & Red: 2nd level \\
\hline $16.06-29.06$ & Phacelia & Purple: 1st level \\
\hline & Crimson, Egyptian and white clover & Red and white: 2 nd level \\
\hline \multicolumn{3}{|c|}{ Plot IV: AU grass mix (Spring sowing) } \\
\hline Blossoming Period & Plant & Blossom \\
\hline $19.05-27.05$ & White mustard & Yellow \\
\hline 28.05-11.06 & White mustard and phacelia & Yellow and purple \\
\hline $12.06-17.06$ & Coriander and phacelia & White and purple \\
\hline $18.06-30.06$ & Coriander & White \\
\hline
\end{tabular}

For Plot II coriander and white clover blossom in in June, as the white blossom dominated in the grass mix.

For the plots with spring sowing (Plot III and Plot IV) the white mustard starts blossoming the earliest as well (19-20.05), but this happened 47 days later, compared to the autumn sowing. Phacelia blossomed in the period 27 May - 11 June. The two species formed two levels: bottom yellow and second predominantly yellow purple. From the middle of June and until the end of that month all clovers (crimson, Egyptian and white) blossomed simultaneously, as the red and white colour dominated in the mix.

For Plot IV solely the coriander blossomed from the second decade of June until the end of the month (18.06-30.06), resulting in predominantly white colour of the stand. 
Summer mowing, after the blossoming of most plants and the commencement of complete maturity, enabled self-sowing of the plants and provided the opportunity for using the areas with the grass mixes for multiple vegetation cycles. This was observed best in the second vegetation year 2015.

After the self-sowing, the predominant species in the grass mixes (Plot II and Plot IV) were phacelia, coriander and white clover. White mustard and buckwheat were destroyed by frost for and could not over-wintering in both plots (Tables 6 and 7).

For the plots with autumn sowing the density of the stands were almost fully preserved with a close ratio of the species in the grass mix. In the spring of 2014 it was $228.4 \mathrm{plants} / \mathrm{m}^{2}$, and in spring $2015-216.6 \mathrm{plants} / \mathrm{m}^{2}$, respectively.

A different stand density was observed for the plots with spring sowing. For the grass mix it was $272.4 \mathrm{pcs} . / \mathrm{m}^{2}$ in in 2014 , and in 2015 the density of the stand was reduced almost in half- $-130.6 \mathrm{pcs} . / \mathrm{m}^{2}$, due to an attack by rodents.

Table 6. Agrarian University grass mix (self-sowing) Plot II (autumn sowing) in 2015

\begin{tabular}{lll}
\hline & Species & \multirow{2}{*}{ Average No. $/ \mathrm{m}^{2}$} \\
\hline Common name & Latin name & 0 \\
White mustard & Sinapis alba L. & 0 \\
Buckwheat & Fagopyrum esculentum Moench & 34.2 \\
Coriander & Coriandrum sativum L. & 22.8 \\
Phacelia & Phacelia tanacetifolia Bentham & 159.6 \\
White clover & Trifolium repens L. & 216.6 \\
Total & & \\
\hline
\end{tabular}

Table 7. Agrarian University grass mix (self-sowing) Plot IV (spring sowing) in 2015

\begin{tabular}{lll}
\hline & Species & \multirow{2}{*}{ Average No. $/ \mathrm{m}^{2}$} \\
\hline Common name & Latin name & 0 \\
\hline White mustard & Sinapis alba L. & 0 \\
Buckwheat & Fagopyrum esculentum Moench & 23.2 \\
Coriander & Coriandrum sativum L. & 2.0 \\
Phacelia & Phacelia tanacetifolia Bentham & 105.4 \\
White clover & Trifolium repens L. & 130.6 \\
Total & & \\
\hline
\end{tabular}

The blossoming period of the plant species in the grass mixes after self-sowing coincided (Table 8).

Table 8. Blossoming period of the grass mixes after self-sowing in 2015

\begin{tabular}{lll}
\hline Period & Plant & Blossom \\
\hline $05.05-27.05$ & Phacelia and coriander & 1st level: Purple and White \\
& White clover & 2nd level: White \\
$28.05-14.06$ & Coriander & 1st level: White \\
& White clover & 2nd level: White \\
$15.06-18.07$ & White clover & White \\
\hline
\end{tabular}

The following plants blossomed from the beginning of May and until the second decade of July (05.05-18.07): phacelia, coriander and white clover. They formed two layers in the grass mix: top purple and white and bottom white only.

\section{Conclusions}

Based on the performed studies, it could make the following conclusions:

$>\quad$ The grass mixes of blossoming plants for attracting pollinators may be composed of the following plant species: white mustard, phacelia, coriander, alfalfa, wild oats, crimson, Egyptian and white clover. 
$>\quad$ For the autumn (second decade of October) and spring sowing (the middle of March) the most suitable plant species for grass mixes are alfalfa, phacelia, wild oats, coriander and various clover species (crimson, Egyptian and white). As a result of the low winter temperatures, the following species were destroyed by frost: white mustard, buckwheat and sainfoin.

$>\quad$ The blossoming in the case of autumn sowing lasted for 60-63 days, beginning from the April and lasting until the beginning of June. In the case of the spring sowing, the duration was 40 days, starting from the second decade of May and until the end of June.

$>\quad$ The plant species phacelia and coriander formed the top level in the grass mix, which was purple- and white-coloured. White mustard, crimson, Egyptian and white clover formed the bottom level—yellow, red and white.

$>\quad$ The summer mowing after the white mustard, coriander, phacelia and white clover reached complete maturity, maintained the grass stand for multiple vegetation cycles.

\section{Acknowledgements}

The present study was funded by "SYNGENTA BULGARIA" LTD. Project 13/2013 in the Agricultural University, Plovdiv, Bulgaria.

\section{References}

Desneux, N., Decourtye, A., \& Delpuech, J. M. (2007). The sublethal effects of pesticides on beneficial arthropods. Annu. Rev. Entomol., 52, 81-106. https://doi.org/10.1146/annurev.ento.52.110405.091440

European Landowners Organization. (2011). Polinators and agriculture. European Landowners Organization.

European Landowners Organization. (2013). Pesticides and biodiversity. European Landowners Organization.

Isaacs, R., Tuell, J., \& Mason, K. (2010). Operation Pollinator Michigam: Phase IA (Michigan State University: Year 1 Report, December 2010).

Johnson, R. M., Ellis, M. D., Mullin, C. A., \& Frazier, M. (2010). Pesticides and honey bee toxicity-USA. Apidologie, 41, 312-331. https://doi.org/10.1051/apido/2010018

Kevan, P. G. (1997). Blueberry crops in Nova Scotia and New Brunswick: Pesticides and Crop Reductions. Can. J. Agr. Econ., 25, 61-64. https://doi.org/10.1111/j.1744-7976.1977.tb02865.x

Klein, A. M., Vaissière, B. E., Cane, J. H., Steffan Dewenter, I., Cunningham, S. A., Kremen, C., \& Tscharntke, T. (2007). Importance of pollinators in changing landscapes for world crops. Proc. R. Soc. Lond. B Biol., 274, 303-313. https://doi.org/10.1098/rspb.2006.3721

Kremen, C., Williams, N. M., \& Thorp, R. W. (2002). Crop pollination from native bees at risk from agricultural intensification. Proc. Natl. Acad. Sci. USA, 99, 16812-16816. https://doi.org/10.1073/pnas.262413599

Larsen, T. H., Williams, N., \& Kremen, C. (2005). Extinction order and altered community structure rapidly disrupt ecosystem functioning. Ecol. Lett., 8, 538-547. https://doi.org/10.1111/j.1461-0248.2005.00749.x

Oldroyd, B. P. (2007). What's killing American honey bees? PLoS Biol., 5, 1195-1199. https://doi.org/10.1371/ journal.pbio. 0050168

Richards, A. J. (2001). Does low biodiversity resulting from modern agricultural practice affect crop pollination and yield? Ann. Bot.-London, 88, 165-172. https://doi.org/10.1006/anbo.2001.1463

STEP. (2007). Status and Trends of European Pollinators FP7 Collaborative Project. Retrieved from http://www.STEP-project.net

Westphal, C., Steffan-Dewenter, I., \& Tscharntke, T. (2003). Mass flowering crops enhance pollinator densities at a landscape scale. Ecology Letters, 6(11), 961-965. https://doi.org/10.1046/j.1461-0248.2003.00523.x

\section{Copyrights}

Copyright for this article is retained by the author(s), with first publication rights granted to the journal.

This is an open-access article distributed under the terms and conditions of the Creative Commons Attribution license (http://creativecommons.org/licenses/by/4.0/). 